\title{
The Study of Moccak Tatak Textual in Pakpak Community
}

\author{
Sitti Rahmah' ${ }^{1}$, Yusnizar ${ }^{2}$, Tuti Rahayu ${ }^{3}$ \\ ${ }^{1,2,3}$ Faculty of Languages and Arts, Universitas Negeri Medan, Indonesia \\ rahmaiyen@yahoo.co.id
}

\begin{abstract}
Tatak Moccak is one of the traditional dances in the Pakpak community which originates from pencak silat or martial arts. Moccak is a term of pencak silat or martial arts which is an element of art that is present in the daily activities of the people. Martial at the beginning of its appearance was closely related to human self-defense against nature. Moccak is adopted from the history of the way of life of the Pakpak people in ancient times who lived in the jungle in a nomadic manner, making humans often encounter wild animals in the forest. This research is an effort to preserve the Tatak Moccak from the Pakpak area through written documentation that discusses in detail the Moccak tatak from a dance point of view. The focus of discussion in this study is the Tatak Moccak in the Pakpak Society analyzed through textual studies. Textual analysis is a method used to obtain and analyze information in academic research. In this case, Moccak's tatak is seen as a text that can be read like a writing. Textual studies in the Moccak style include choreographical, structural, and symbolic studies. Choreography discusses dance movements, movement techniques, movement styles, number of dancers, gender and body posture, space in Moccak's style, time, dance accompaniment music, dramatic analysis, and stage techniques (lighting, make-up, and fashion). includes the structure of the motion and structure of the presentation of the Moccak layout. Symbolic discusses symbols in movement, costumes, and make-up.
\end{abstract}

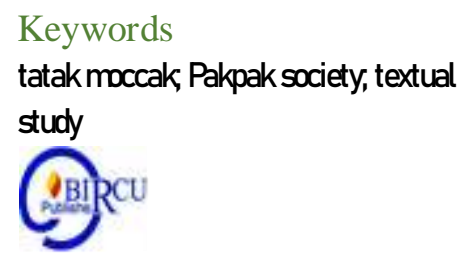

\section{Introduction}

Traditional dance is the work of human creation and inventiveness which is passed on from one generation to the next. A traditional dance style does not remain in shape. He will always change when taught by the previous generation to the next generation, because the form of dance that is inherited must be interpreted. Traditional dance will continue to be preserved if there is continuous renewal and development by its supporters. Development and renewal can be done by individuals or groups, either in the form of internal perceptions or external perceptions. (Adlin, 2020)

Dance is a statement or reflection of the culture of the supporting community. As a reflection or cultural expression, dance communicates the conditions that exist and are owned by the supporting community. "Dance as a nonverbal language is able to provide the identity adopted by its supporters through the style they have. (Nugrahaningsih, 2020)

According to Febrianto in Martozet (2020) dance is an expression of the soul of human art expressed through beautiful movements and rhythms that give satisfaction to others. The beautiful movements and rhythm are actually the radiance of the human soul and the soul is usually in the form of reason / ideas, will and emotions.Rahmah (2019) states traditional art as one of the material that must be studied, so far has been taught only by oral tradition, focusing on dance 
Pencak silat and dance are related and complementary expressions, because both use the human body as the main material and contain elements of the beauty of the movement of the whole body in harmony. To beautify the resulting movements, people used to combine them with elements of dance, so that this movement was easy on the eyes and able to be controlled by the wider community.

Moccak is a term of martial arts or martial arts in the Pakpak Dairi community which is an element of art that is present in the daily activities of the community. Moccak is adopted from the history and way of life of the Pakpak people in ancient times that were still alive and living in the jungle with a nomadic way of life. An unsettled place of residence makes humans often encounter wild animals or animals in the forest. In order to protect themselves, humans must face the wild animal by themselves with the means that they have, for example facing or fighting a tiger (biahat), humans use hunting tools, namely spears and controlled hunting moves. According to Morris (1977), martial arts at the beginning of its appearance were closely related to human self-defense against nature. This linkage can be identified since prehistoric times. Humans have always tried to defend themselves from attacks by enemies, be they nature, animals, or fellow humans who are considered to threaten their integrity.

Furthermore, moccak is combined with movements that contain elements of beauty into dance performances for the Pakpak community. Tatak is a term or designation "dance" in the Pakpak Tribe, which is one of the eight tribes in North Sumatra Province.

Tatak Moccak is one of the traditional dances that exist in the Pakpak community. Tatak Moccak is well known to the Pakpak community because it is often performed in welcoming ceremonies for guests or traditional figures from inside or outside the Pakpak area.

Tatak Moccak is performed by two or more male dancers in pairs with predetermined movements. Tatak Moccak is presented with a performance action in the form of a dance that originates from the movements of the martial arts (martial arts) and is accompanied by traditional music accompaniment of the Pakpak Community, also known by several names, namely Gendang Raja, Gendang Sipitu, and Mendegger Uruk. In an interview with Sangka Manik, a Pakpak traditional artist (15 May 2020) said that the Tatak Moccak has become a traditional dance which has been carried out from generation to generation until it is no longer known who its creator is. The view of traditional dance according to Soedarsono is all dances that have experienced a long history, which always relies on existing traditional patterns (1978: 29). Soedarsono's opinion emphasizes that the existence of traditional dances has existed and developed for quite a long time, growing from the past to continue to exist today.

Tatak Moccak as a cultural art The Pakpak community also lives and grows in Simpang Kiri District, Subulussalam City as a place / location for the research being carried out. In the previous author's book there is an explanation of the Pakpak tribe consisting of 5 sub-tribes, in local terms it is often referred to as Pakpak Silima Suak. The Pakpak community in Simpang Kiri Subulussalam is included in the Pakpak Boang Tribe group (Aceh-Singkil Regency and Subulusalam City-Aceh) Aceh Province (Rahmah, 2018: 1)

In its appearance, Tatak Moccak presents attack and deterrence movements that describe one's self-defense against threats from an incoming attack. This Tatak Moccak dancer must first master basic movements such as leg movements, stances, hands to the upper body. Pencak silat movements as the basis for coloring this dance, were developed and modified into a Pakpak ethnic dance which is usually performed as a welcome dance for large guests who come to this area. The presence of tatak moccak as an art form in the 
Pakpak community is an expression related to the life needs of the community, as well as part of a social process that has various functions according to the context of needs.

The function of dance is the existence of dance that has value and useful results that benefit society, especially in social life (Hidayat, 2005: 5). As Jazuli said, the functions of dance include: 1) Dance for Ceremonies (religion used in religious events, customs that are directly related to the interests of the community in their environment as long as customs are still used, customs related to human life events such as birth, marriage, coronation, and death); 2) Dance as entertainment to convey the heart or art pleasure; 3) Dance as a show and spectacle, namely showing something that is considered art, but always tries to attract attention and can provide satisfaction as long as the mental aspect involves itself in the show and gets an impression after being enjoyed so that it causes changes and new insights; and 4) Dance as an educational medium that can help shape human beings completely and in harmony with personal development that takes into account the social, cultural and relationship with God (1994: 43 - 46).

\section{Review of Literature}

Basically, the implementation of moccak indirectly also has various functions in the Pakpak community, including:

1. As entertainment

In the past, Moccak performances became entertainment for the Pakpak community because there were no sharing activities and entertainment facilities such as: malls, shopping centers, cinemas, etc. The community makes Moccak shows an activity that can cheer up their hearts during their spare time after being tired of work.

2. As a means of traditional learning

Watching Moccak performances basically provides direct learning about Pakpak customs and culture to the community about silat movement movements that are conditional on meaning, as well as the rhythm of the music produced by playing the accompanying musical instruments. Through this performance, the community can understand the traditional meaning of ancient people's habits in terms of hunting.

3. As Training Cooperation

In the implementation of moccak performance activities, in essence, you can train teamwork, namely between moccak actors in pairs and with musicians. To create harmony between the funny actors, they must practice the movements with their co-stars so that there are no accidents in performing silat movements. Besides that, it is also necessary to practice together with musicians, must have good communication in the training process so that a neat and attractive game is realized in the performance.

4. As Education

The collaboration that exists in the funny training process until the show has essentially an education going on in it. The moccak performance also acts as an education when the community of actors and connoisseurs can learn and apply it to their daily lives in learning martial arts. Through this performance, it can be used as teaching material for students to gain insight into the appreciation of traditional arts from a region.

In this hilarious study, the author focuses more on the discussion of contextual studies, which are seen as a text that can be read like a writing that has its own meaning. The guideline that the author uses as a basis for thought is Y.Sumandiyo Hadi (2007: 21) which states that studying a dance can be textually analyzed which is seen as a relatively independent physical form (text), which can be read, examined or analyzed. textually 
according to the reader's concept of understanding the text. This textual study in the phenomenon of dance can be analyzed from a choreographic, structural, and symbolic perspective (Hadi, 2007: 21-23).

Textual studies in the Moccak style include choreographic, structural, and symbolic studies. From a choreographical perspective, textual analysis means that the dance is described or its movements are described, from the movements that appear physically. Koregrafi is a term that comes from Greek, namely Choreia means dance together, and Graphia means writing. Furthermore, in the world of dance is more defined as knowledge of dance arrangements or dance creations (Murgiyanto, 1983: 3-4).

Choreographical analysis is intended to discuss the dance movements, movement techniques, movement styles, number of dancers, gender and body posture, space in Moccak style, time, dance accompaniment music, dramatic analysis, and performance techniques (lighting, make-up, and fashion). Structural analysis can be analogized as a grammar in the world of dance, so that it can be read and defined as a set of relationships between one motion and another, in the form of dance (Hadi, 2007: 81). Structural analysis includes the structure of the motion and the structure of the Moccak presentation structure. Symbolic analysis views that every dance that is read as a text that needs to be interpreted. Symbolic analysis in dance can be understood that the dance movement symbol system is a sign which is a representation of its creator who has its own message (Hadi, 2007: 90). Symbolic analysis in this study is used to discuss the symbols in motion, costumes, and make-up.

Through this research, the authors hope to preserve Tatak Moccak and generate a love for dance for the Pakpak community in the village of Suka Makmur Subulussalam in particular and the Pakpak community in the West Pakpak area, and Sidikalang in general.

\section{Discussion}

This research is a qualitative descriptive study. The data collection technique uses observation, interview and documentation methods. Observations were made at the Arihta Karina Cultural Center, Jambu Mbelang Hamlet, Simpang Kiri District, Subulussalam City, which in general are the Pakpak tribe, to observe dance forms directly. During the observation and at the same time interviews were conducted with Pakpak traditional artists named Mr. Sangka Manik and Arden Lembong who generally know about the moccak tattoo. Documentation studies are used to record all the information needed to collect research data in the form of photos and videos as evidence to strengthen the results of this study.

The textual study of moccak in the discussion of the results of this study will be described in a unified choreographical, structural, and symbolic analysis in the moccak style which can be explained through the form of motion and the variety of motion and its meaning, the accompanying music and the type of musical instrument, as well as the moccak style, which can be detailed as following:

\subsection{Motion Forms and Variety of Moccak Patterns a. Initial Attitude}

The initial attitude in dance is the position of getting ready before starting to perform various movements. This initial gesture is carried out with the legs standing upright, strong, confident, and the position of the palms together as if greeting guests. 

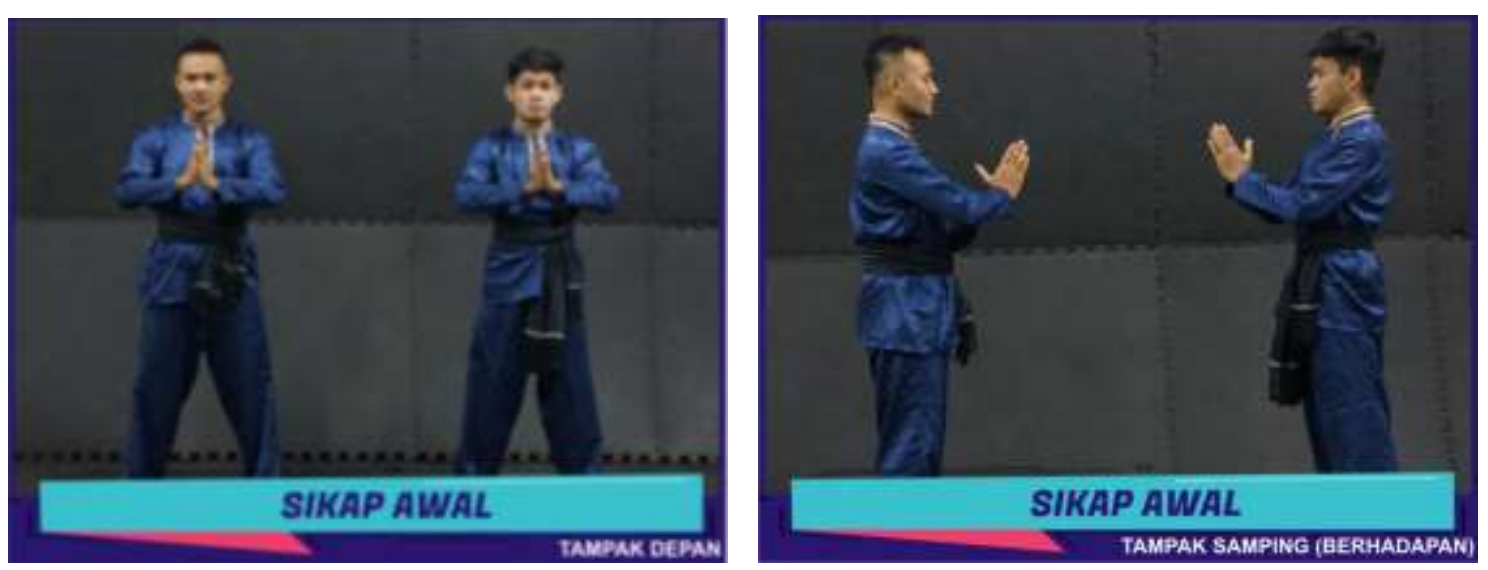

\section{b. Salam Persintabin}

Salam persintabin or salutations are divided into 4 forms of motion, namely 2 types of salutations, opening salutations and closing salutations. The motive of the Salam Persintabin movement means that the Pakpak community has an attitude of respect for guests / visitors who come to attend the event that is being held. The Pakpak community highly appreciates and upholds cultural values that are reflected in actions, actions that indicate a sense of reverence or respect (such as worship, bowing): to other people / guests who come.
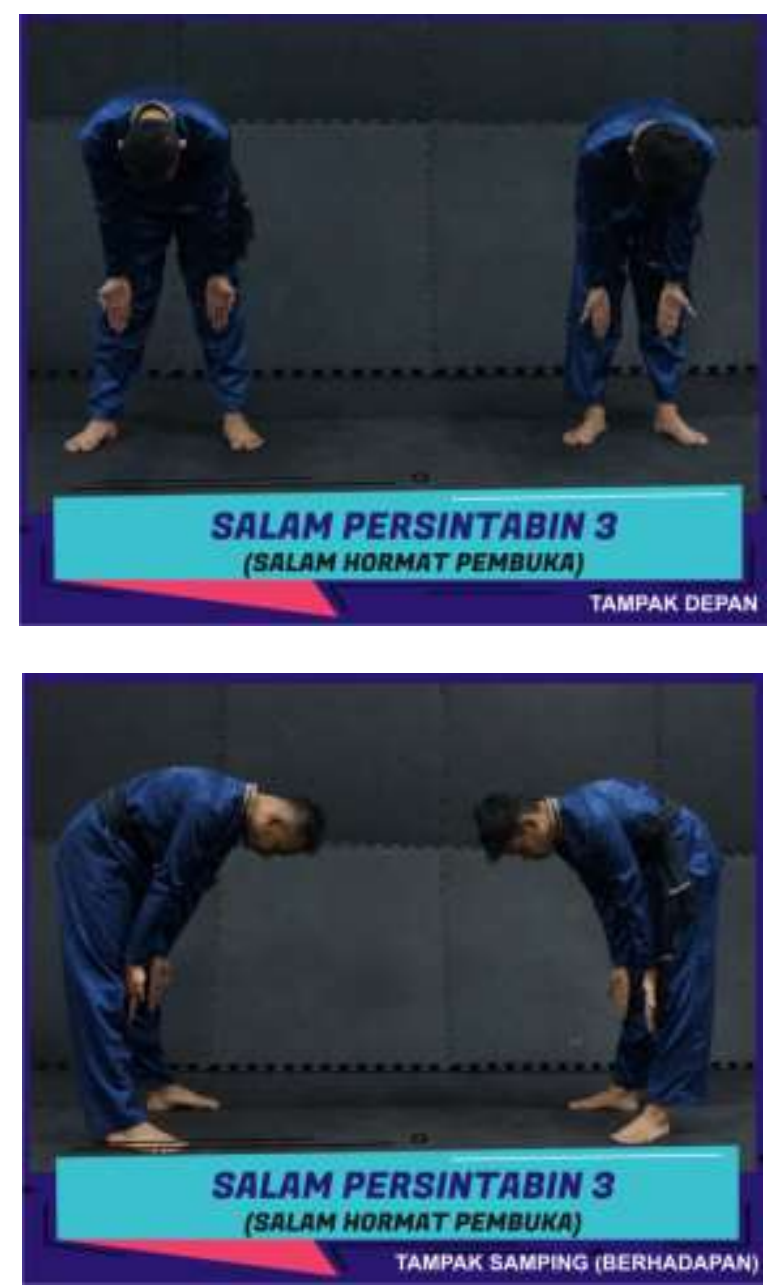


\section{c. Kipasang Kuda-kuda}

Kipasang kuda kuda is a motive for movement carried out by the feet, in which the position of the legs is opened wide and the legs are bent as low as possible, giving the impression of a manly fighter or defender.

The motive of the Kipasang Kuda-Kuda movement means being alert or alert (in martial arts) with the position of the legs and body ready to receive incoming attacks.
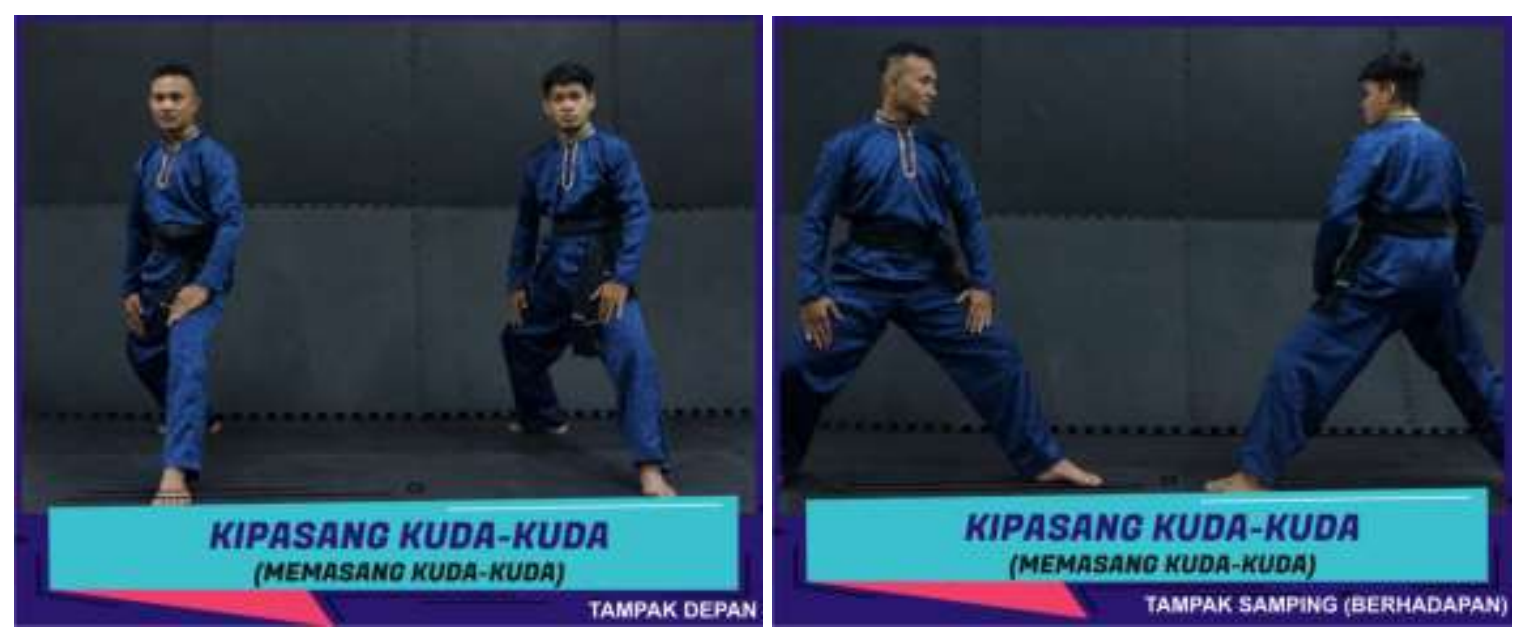

\section{d. Merelak Kambirang Kamuhun}

Merelak kambirang kamuhun or dodge left to right is a motive for movement performed by a combination of foot and hand movements. This motive is carried out by opening the right leg or left foot back, followed by the body that throws its way and the hand is raised to the right or left and slowly moved freely as if it were avoiding an opponent's attack.

The motive of the Merelak Kambirang Kamuhun movement has the meaning of the attitude of dodging or avoiding the opponent's attack (protecting oneself from the opponent's attack) by moving left and right.
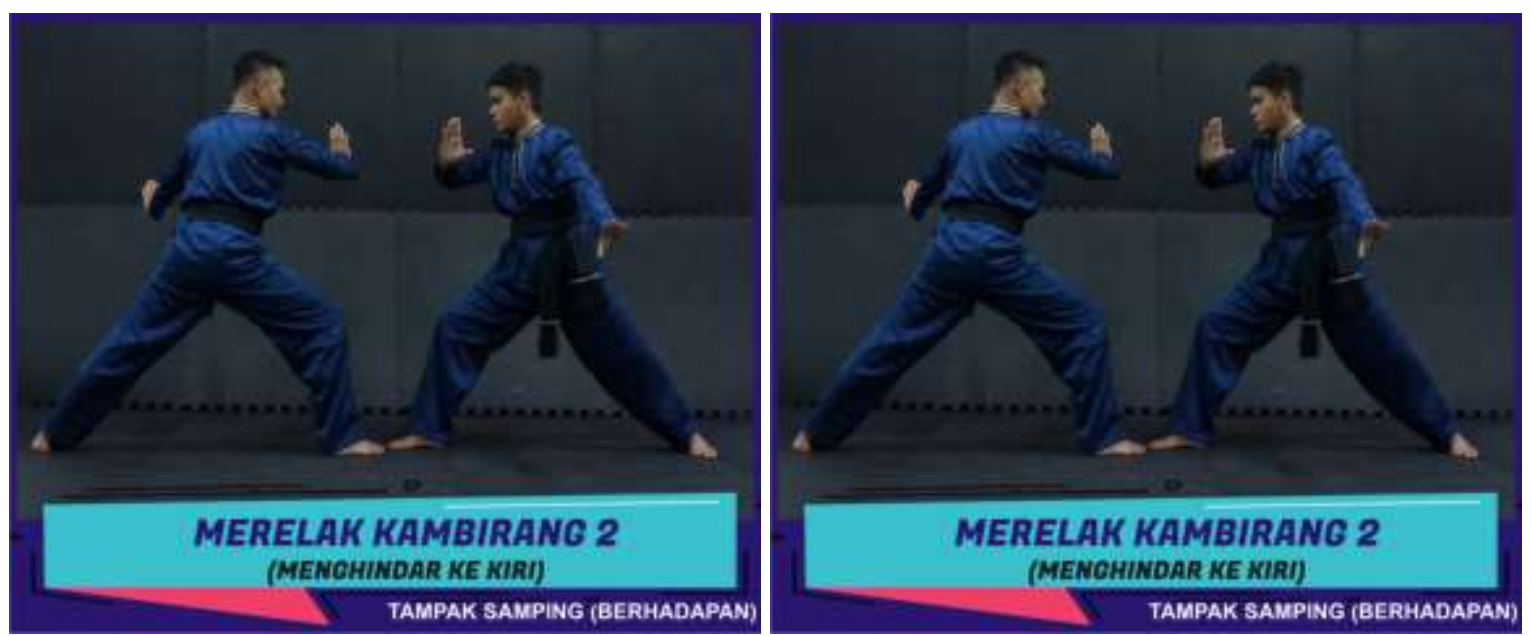


\section{e. Kitenju Alo}

Kitenju alo or hitting the opponent is a motive for movement carried out by the hand by clenching the fist and striking / hitting the opponent on the part of the opponent's body that wants to be attacked. The motive for the Kitenju Alo movement means attacking the opponent by punching or hitting the opponent's body.
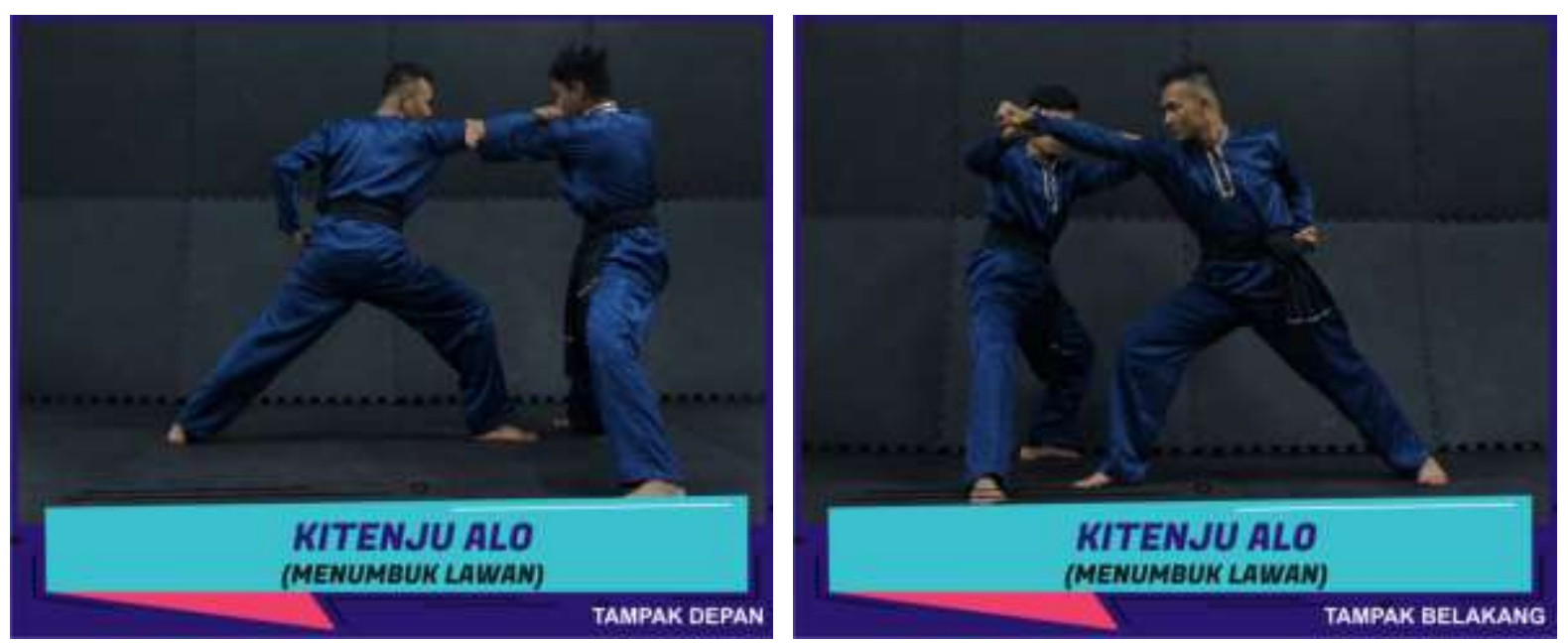

\section{f. Kitangkap Tangan Alo}

The movement motive for Kitangkap Tangan Alo means to catch the opponent's hand which is done to receive as well as block and stop attacks coming from the opponent. The motive for the movement of Kitangkap Tangan Alo is carried out simultaneously by dodging the body and directing the hand to the opponent's wrist while grasping and holding it.
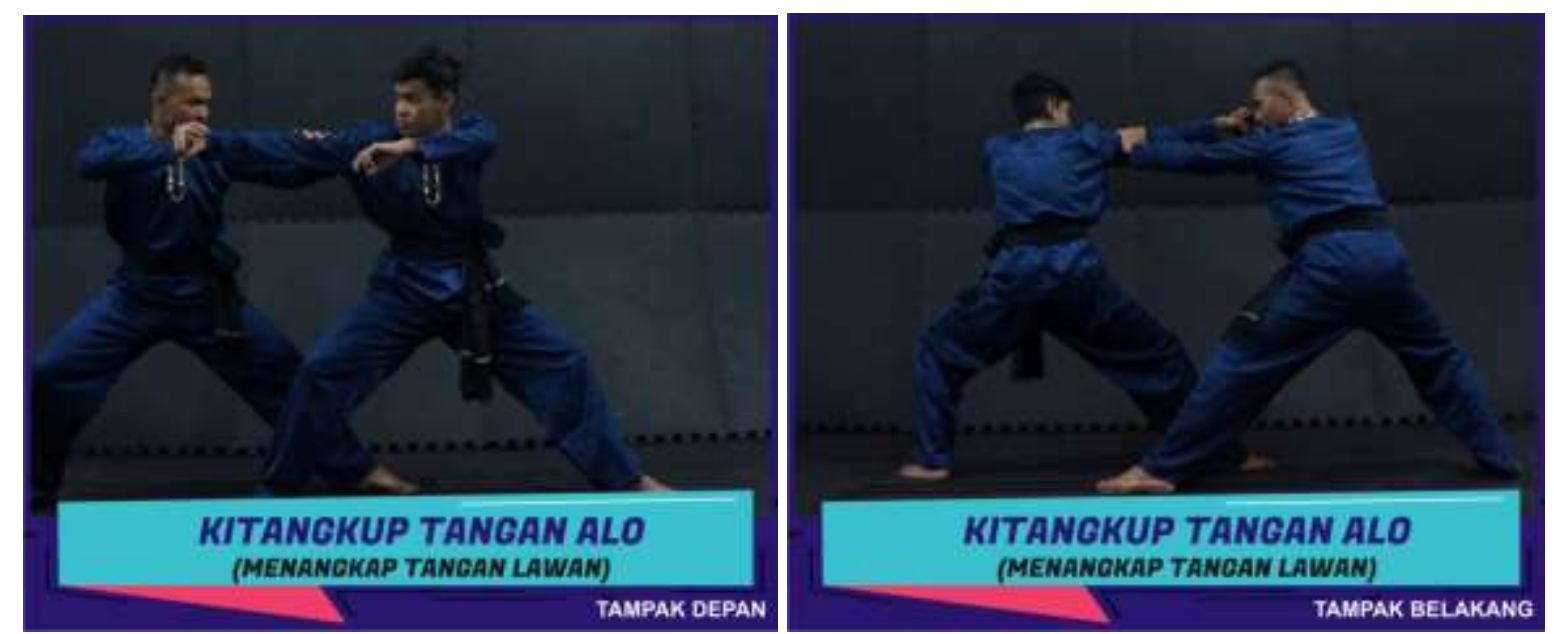

\section{g. Mendabuhken Alo}

The motive for Mendabuhken Alo has the meaning of bringing down the opponent. This motion motive is carried out after capturing part of the opponent's hand, leg, or neck so that there is a platform to knock the opponent down. 


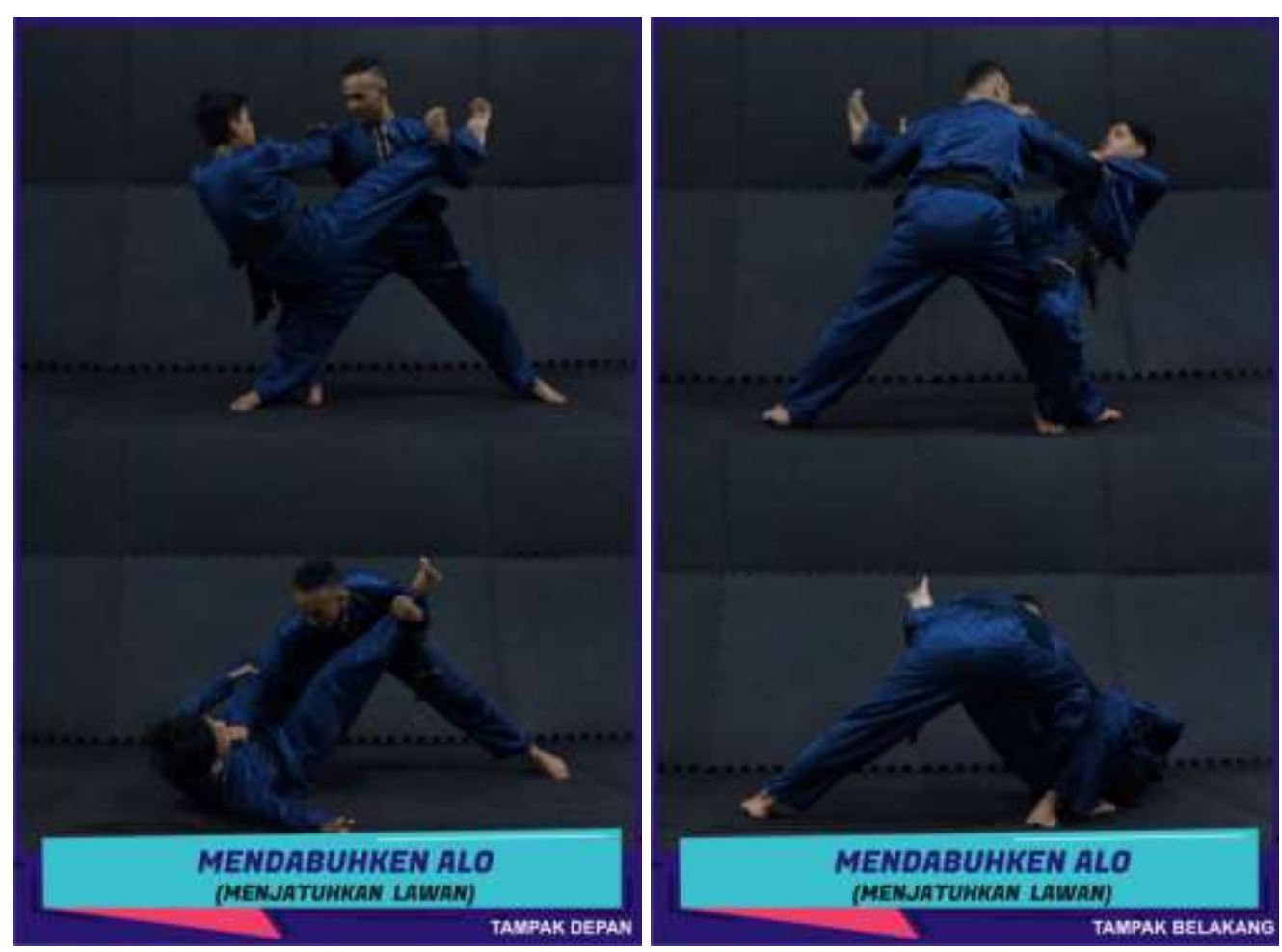

\section{h. Kisepak Alo}

Kisepak Alo's motive means kicking the opponent which is usually aimed at the opponent's arm or back to counterattack. Kisepak Alo's motive is carried out by lifting the leg towards the opponent's arm or back.
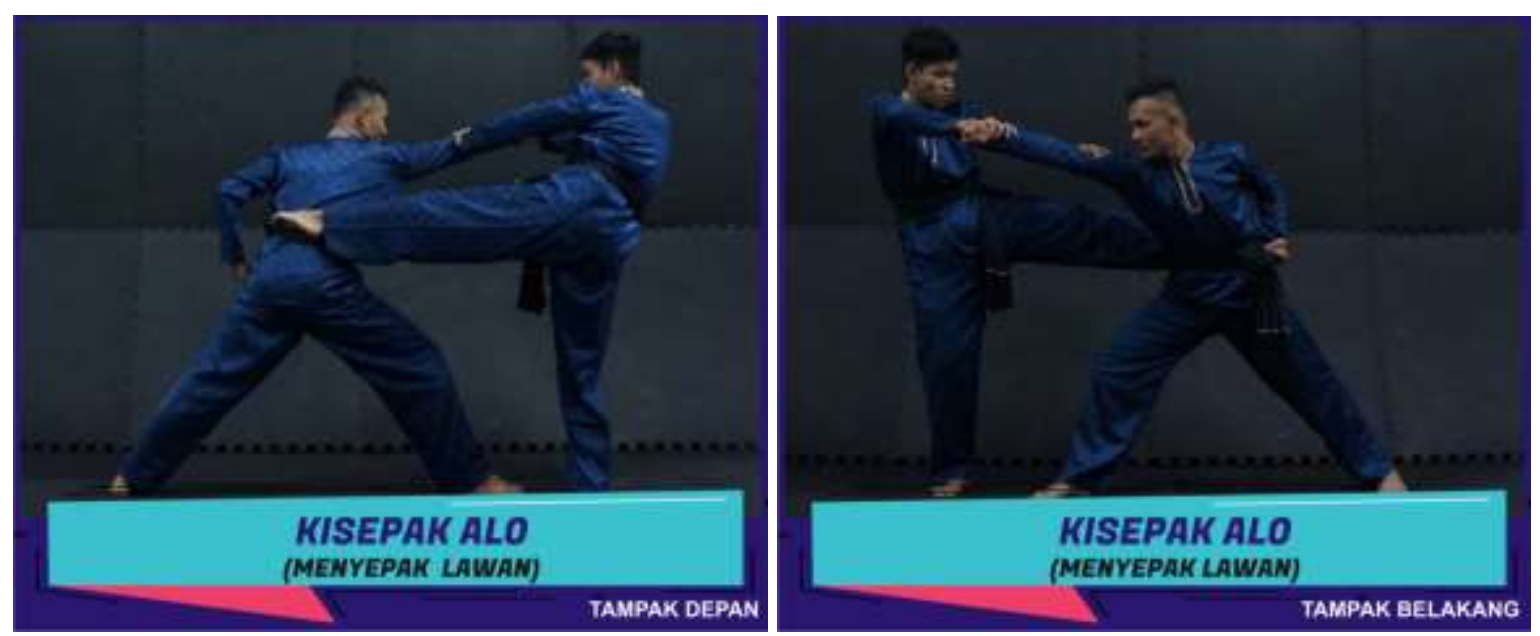

\section{i. Kitangkup Sepaken Alo}

The motive of the Kitangkup Sepaken Alo movement has the meaning of capturing the opponent's hand which is carried out as a defense from attacks by the opponent. The motive of this movement is carried out by directing the hand towards the opponent's leg and catching it using the grip of the hand and can also use the inner elbow. 

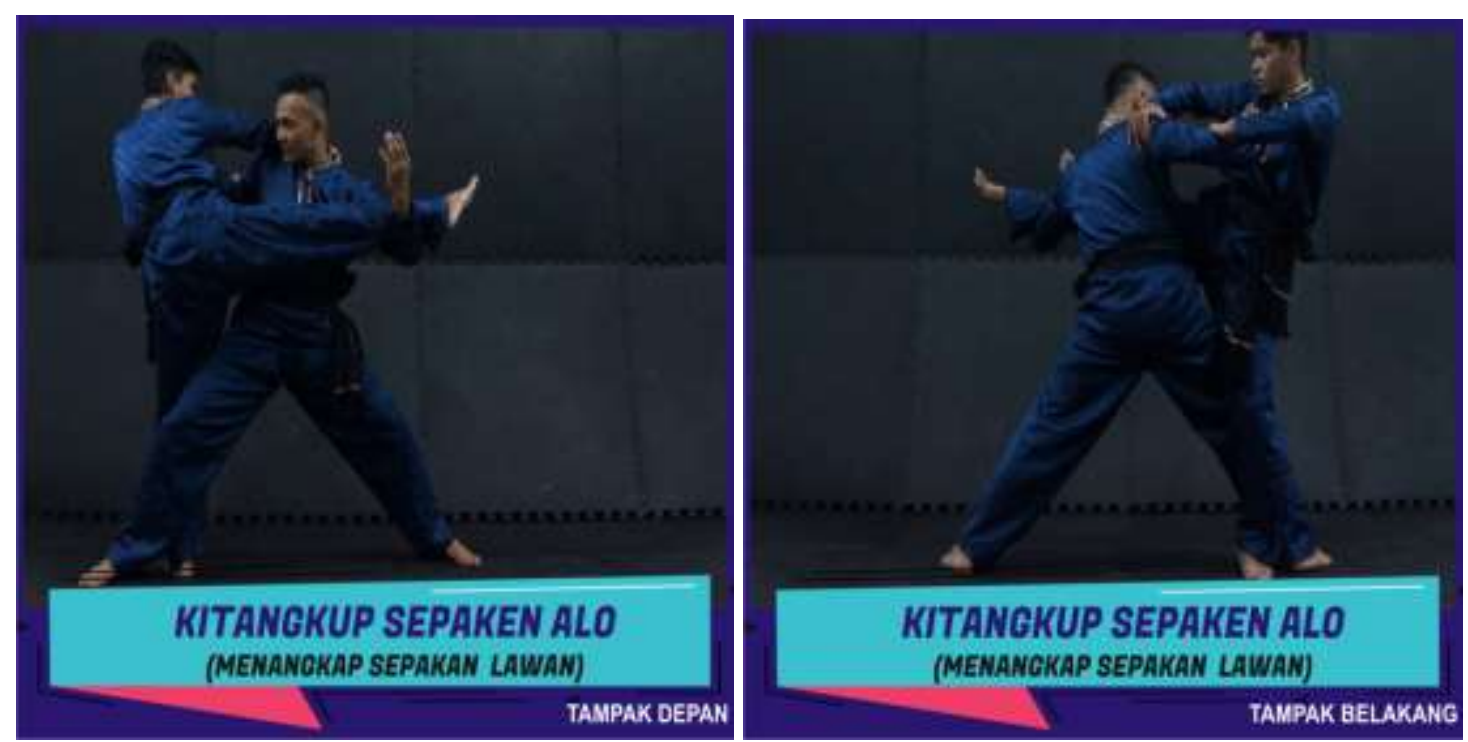

\section{j. Kisekkuken Alo}

Kisekkuken Alo's motive means attacking the opponent with the elbow. The motive for this movement is usually done after menangkap tangan Alo or Kitangkup Sepaken Alo with one hand holding the opponent's hand or leg and one hand elbowing the opponent's arm or chest.
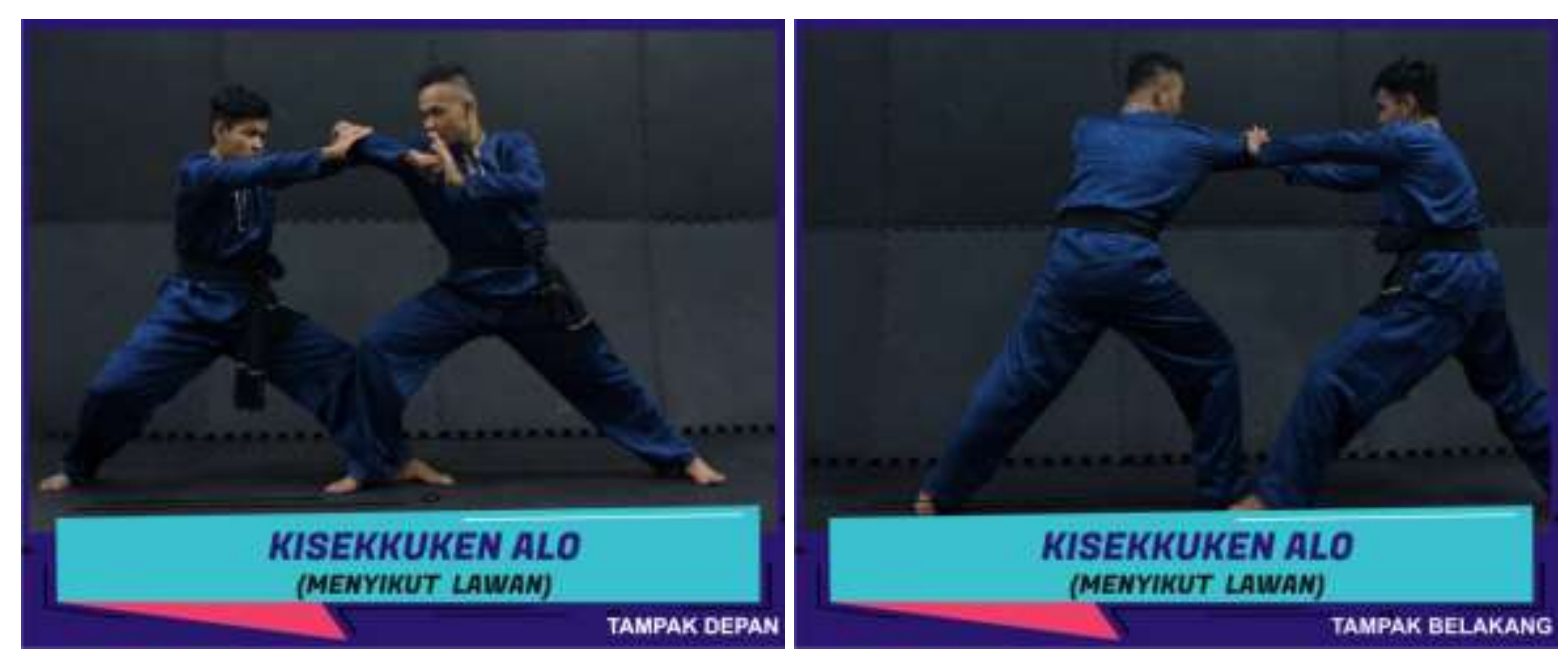

\section{k. Kicuakken Kerahong}

Kicuakken Kerahong motive means breaking the neck as an attack while knocking down the opponent. The motive for this movement was also carried out after menangkup Sepak Alo with one-hand movement to catch the opponent's kick and one hand to attack the neck while dropping the opponent. 

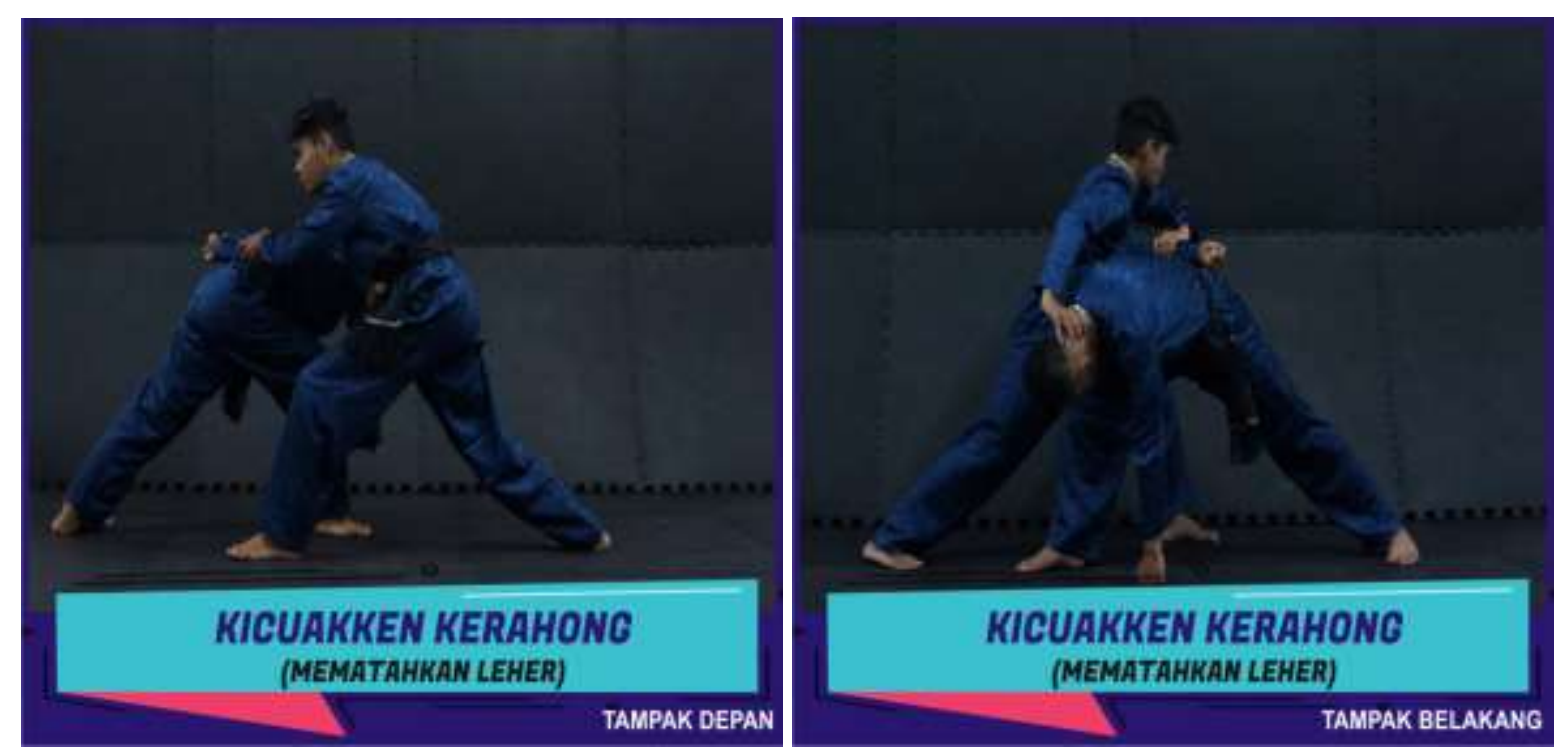

\section{Kitunjang Podi Nai}

The movement motive for Kitunjang Podi Nai means kicking your opponent from behind. The motive for the movement of Kitukung Podi Nai is to reverse the body and lift the legs towards the back while directing the feet towards the opponent's chest.
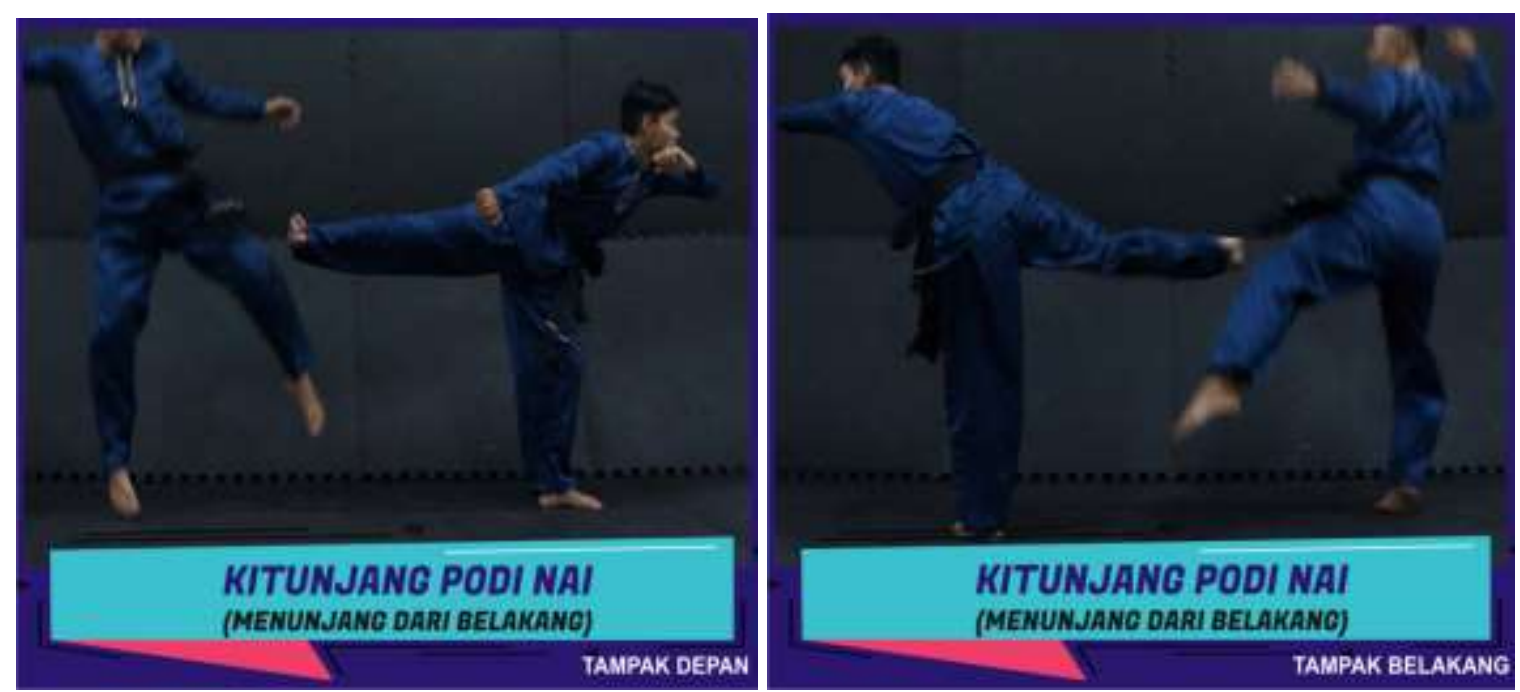

m. Salam Persintabim (Closing)

Salam Persintabim or closing salutations. The motive of the Salam Persintabin movement means that the Pakpak community has an attitude of respect for guests / visitors who come to attend the event that is being held. 

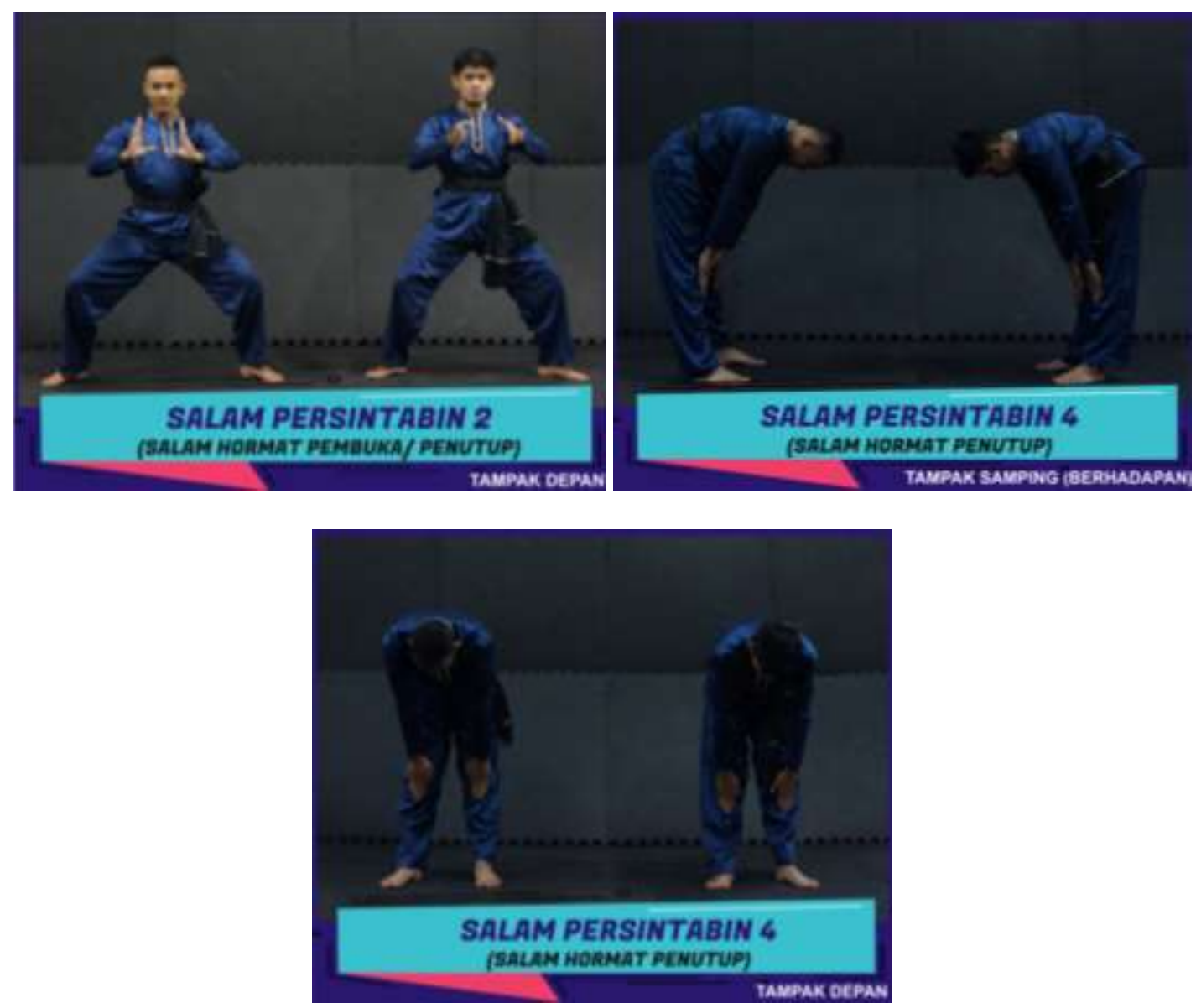

\subsection{Music to accompany Tatak Moccak}

The accompaniment music that is usually played to accompany Tatak Moccak is a traditional music accompaniment of the Pakpak Community, also known by several names, namely Gendang Raja, Gendang Sipitu, and Mendegger Uruk. Traditional musical instruments that are commonly used to accompany the tatak Moccak performance are the gendang sipitu and gung sada raban, which can be described as follows:

\section{a. Gendang Sipitu}

Gendang sipitu is a drum-like instrument consisting of seven drums with different tones. This drum is made of wood and cow or buffalo leather. The instruments are in the form of two logs which are used by each musician. These seven drums are part of the genderang Sisibah. It is said that the drums are like that because only seven drums were beaten in accompanying the Tatak Moccak.
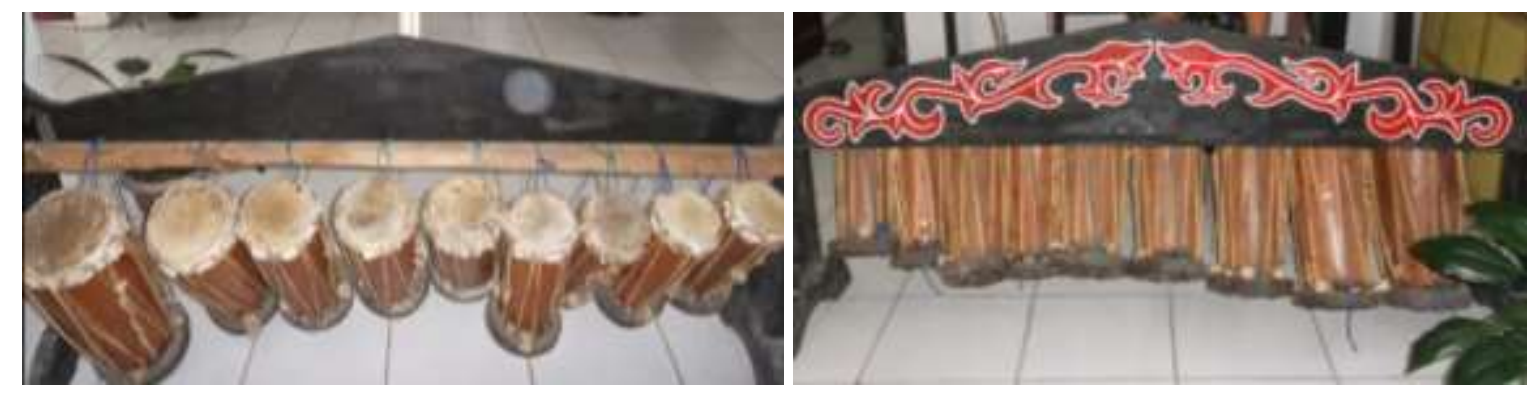


\section{b. Gung Sada Rabaan}

Gung in ancient times was made from a mixture of silver, kangsa, copper, gold, and various other mixtures to produce a gung with a loud sound. However, at the present time most of the gongs are only made of a few mixtures of iron and copper. The gung that accompanies Tatak Moccak consists of two gongs and is played by two players by beating them.

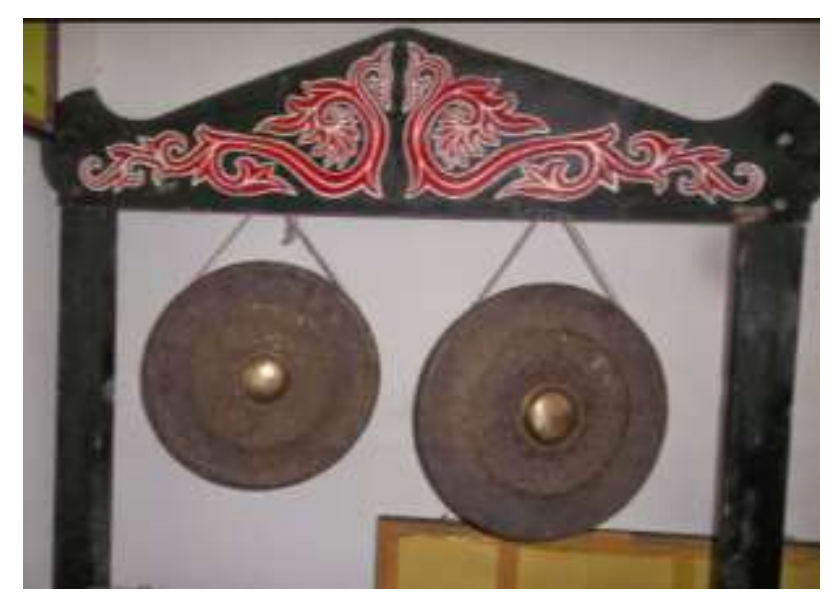

\subsection{Tatak Moccak Clothing}

\section{a. Baju Merapi-Api}

Black long-sleeved shirt spiked with or decorated with beads (Api-api). The type of fabric that is commonly used is a type of velvet but has recently been more adapted to the latest styles and types of fabrics and different colors. There are several other variations attached and on the neck and cuffs there is a red and white color.
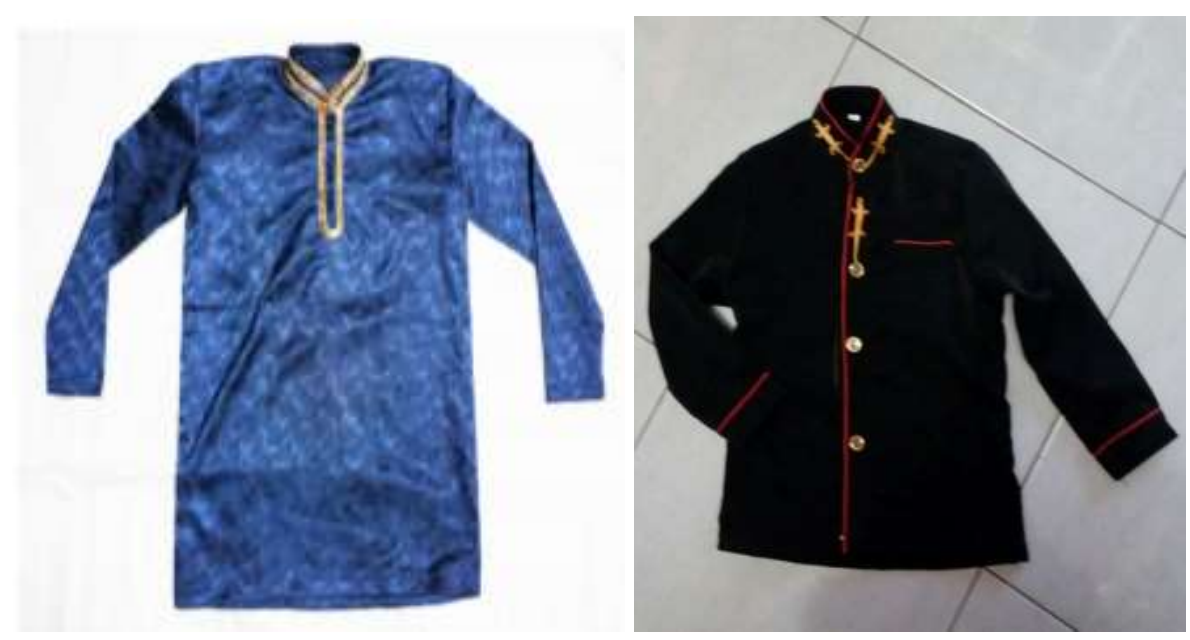

\section{b. Long pants}

The trousers are basically black to match the clothes, but they can also be adapted to the current model by adjusting the color of the clothes, usually just plain and there are no additional knick-knacks in them. But now there are many new variants that add to the ends there are also red and white variations or the like that make it more attractive. The size generally does not touch the toes of the feet but is in the middle position, like the pants that are usually used by atil silat or karate. 


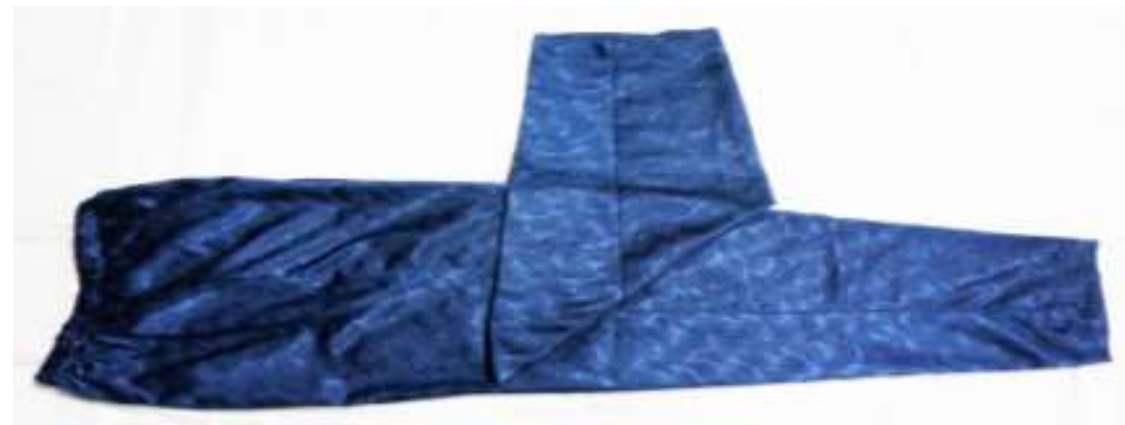

\section{c. Bulang-Bulang}

Bulang-Bulang is a head covering, a symbol of honor and dignity, which is shaped in such a way as to spread the flower of the bean. The head covering on the moccak tattoo can also be tied only to the head without being made into a shape with the intention of avoiding the headdress falling during the rolling motion.

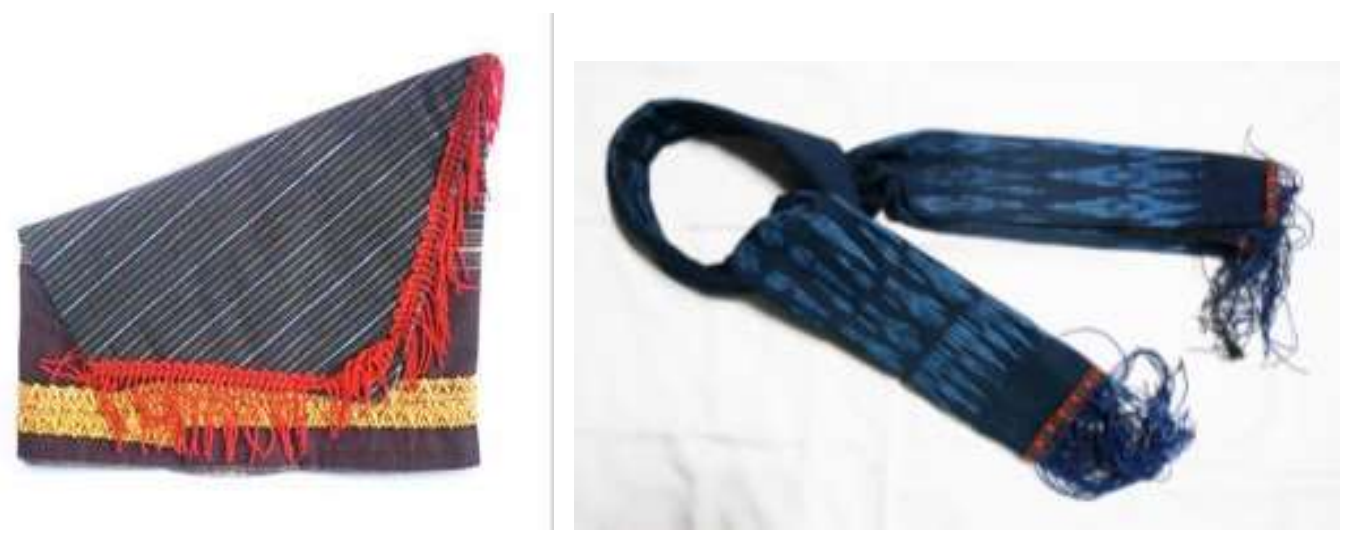

\section{d. Sarung (Oles Sidosdos)}

Oles Sidosdos is a trouser cover that is wrapped around the waist with an open end at the front.

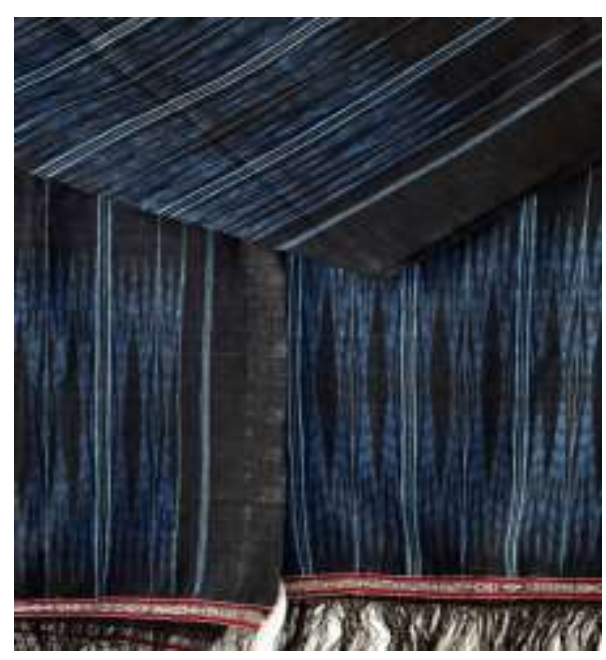




\section{e. Borgot}

A necklace made of gold, either pure gold or silver overlaid with gold. It really depends on the economic ability of the owner or user. A series of gold tied with Sitellu-like thread and at the end there is a necklace with a buffalo head on it. The series consists of 32 pieces. This Borgot is usually only used by certain people such as officials who are present and want to join the dance together when they come and are greeted with hilarious looks.

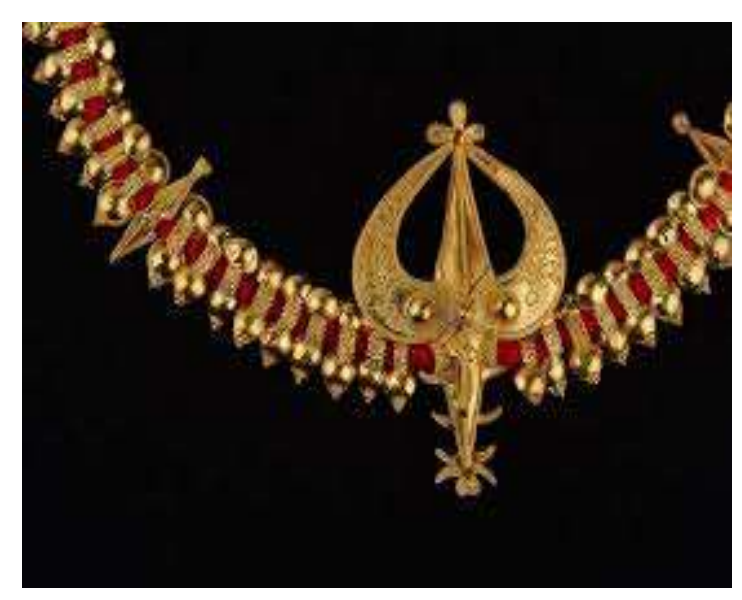

\section{f. Sabe-Sabe}

Oles Polang-polang or oles Gobar, placed on the right shoulder, unraveling from back to front. Apply folded and adjusted to the style of the basting.

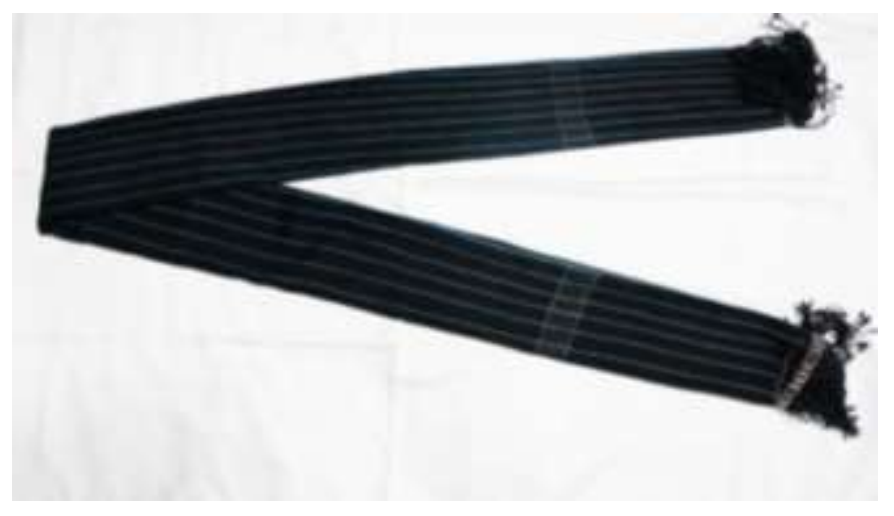

\section{Conclusion}

The results of research on the textual look at the Pakpak community, it can be concluded that:

1. Discussion of textual studies of Tatak Moccak's layout in terms of choreographical, structural, and symbolic aspects. Textual analysis in terms of choreographical form of moccak is described or described physically visible movements. The movements in tatak moccak as a whole describe the movement of martial arts (pencak silat) which includes resistance, defense, and parry from opponent attacks. The number of Moccak tatak dancers can be performed by two or more male dancers.

2. Analysis of the tatak moccak structure seen from the structure of the motion and the structure of the presentation where the movements are composed from the start starting the dance from the initial attitude, giving greetings (salam persintabim), the motion of putting 
up a stance (kipasang kuda-kuda), avoiding the opponent's attack (merelak kambirang kamuhun), attacking motion (kitenjo alo), evasive and holding motion (We catch Alo's hand, knock down the opponent (Mendabuhken Alo), kick the opponent (Kitangkup Sepaken Alo), attack with the elbow (Kisekkuken Alo), motion to break the neck ( Kicuakken Collarong), a kicking motion (ki tukung podi nai), closing greeting motion. The overall structure of the tatak moccak presentation is presented through a variety of movements that are strung together in a unified dance form in harmony with the rhythm of the music accompanying the Gendang Raja.

3. Symbolic analysis is needed to interpret all elements of a moccak pattern that can be understood from the motion symbol as a sign, which represents the creator's own message. The movement of presenting the Pakpak dance / tatak in general begins and ends with a persintabim greeting which is a symbol of respect and high esteem for cultural values that are reflected in actions, actions that indicate the solemnity of the Pakpak Community to other people / guests who come The symbolic presentation of the tatak moccak has a function as an activity that can entertain the heart during spare time after being tired of work, through this show the community can also understand the customary meaning of ancient people's habits in terms of hunting.

\section{References}

Adlin, D. (2020). Aesthetic Concept - Choreography of Piso Surit Dance in Karo Community. Budapest International Research and Critics in Linguistics and Education (BirLE) Journal. P. 172-182

Hidayat, R. (2005). Wawasan Seni Tari. Artikel. (Diterbitkan). Malang: Jurusan Seni dan Desain Fakultas Sastra Universitas Negeri Malang.

Hadi, Y. Sumandiyo. (2007). Kajian Tari Teks dan Konteks .Yogyakarta : Pustaka Book Publisher.

Jazuli M. (1994). Telaah Teoritis Seni Tari. Semarang: IKIP Semarang Press.

Nugrahaningsih, R. (2020). Manduda Dance in Simalungun Community Dancing Style in a Contextual Perspective. Budapest International Research and Critics in Linguistics and Education (BirLE) Journal. P. 164-171

Martozet and Nurawani. (2020). The Transformation of Karo Traditional Dance Movementin Modern Choreography Form GegehGundala-Gundala. Britain International of Linguistics, Arts andEducation(BIoLAE) Journal. P. 765-775.

Murgiyanto, Sal. (1983). Koreografi Pengetahuan Dasar Komposisi Tari. Jakarta : Departemen Pendidikan dan Kebudayaan

Rahmah, Sitti. (2018). Terminology Gerak Tari Pakpak. Medan:UNIMED Press

Soedarsono. (1978). Tari-tarian Indonesia I. Jakarta: Balai Pustaka. 